\title{
Molecular Composition and Optical Properties of Brown Carbon Generated by the Ethane Flame
}

Christopher P. West ${ }^{1}$, Anusha Priyadarshani Silva Hettiyadura ${ }^{1}$, Andrew Darmody ${ }^{1}$, Gaurav Mahamuni $^{2}$, Justin Davis ${ }^{3}$, Igor Novosselov², Alexander Laskin ${ }^{1, *}$

${ }^{1}$ Department of Chemistry, Purdue University, West Lafayette, Indiana, 47906

${ }^{2}$ Mechanical Engineering, University of Washington, Seattle, Washington, 98195

${ }^{3}$ Molecular Engineering and Science Institute, University of Washington, Seattle, WS, 98195

\section{Table of Contents}

Appendix A. Particulate Matter (PM) Sampling Information, TOC Analysis

Appendix B. Determination of MACoc from HPLC-PDA Chromatographic Data

Appendix C. Calculation of Emission Factor of Benzo[a]pyrene

Figure S1. (a) Schematic and image of inverted gravity flame reactor (IGFR) (right). (b) Sequence of diluted flames (left) from low (colder) to high (hotter) temperature depicting variations in flame brightness

Figure S2. (a) Figure of merit showing the accuracy of assigned elemental formulas via direct infusion (+/) ESI/APPI-HRMS detection (combined) on QE-HF-X Orbitrap ${ }^{T M}$ (Thermo, USA). Assigned formulas in ESI data is color coded in blue while APPI data in red. Histograms (b) and (c) represent normally distributed formula assignments in APPI and ESI

Figure S3. Hydrogen to carbon (H/C) ratio vs carbon plot for EEF191 (80\% Dilution) sample

Figure S4. LC-PDA chromatograms representing ethane fuel combustion samples at various dilutions of the flame in IGFR experiments

Figure S5. Upper panel: 3D LC-PDA chromatogram of OC fraction extracted from PM sample collected in EEF 196 experiment (0\% dilution). Lower panels: Individual absorbance spectra of 7 selected BrC chromophores with assigned elemental formulas, corresponding DBE and Al values, and examples of their possible structures

Figure S6. Histogram of oxygen to carbon $(\mathrm{O} / \mathrm{C})$ ratio for individually assigned species binned to the sum of MS peak intensity

Figure S7. Relative contribution of the 25 most absorbing BrC species detected in five PM samples collected in the ethane flame experiments (EEF196-EEF192), with respect to the total BrC absorption determined by each of the samples, respectively

Figure S8. Mass absorption coefficients (MAC) and angstrom absorption exponent $\left(\lambda^{-A A E}\right)$ of all BrC samples (EEF196-EEF192) examined in this study 
Figure S9. Graphical representation of the optical-based BrC classes in $M A C_{405 n m}-W$ space. $B r C$ classes are grouped according to their optical and physicochemical properties within 5 general classes of $B r C$ and $B C$

Table S1. Summary table of all optical and relevant molecular information for BrC compounds

\section{References}


The supporting information includes mass and optical information of brown carbon $(\mathrm{BrC})$ chromophores and other components generated in combustion experiments via high performance liquid chromatography, photodiode array and high-resolution mass spectrometry with atmospheric pressure photoionization (LC-PDA-APPI/HRMS) platform.

Appendix A describes PM sampling in the IGFR experiments and other experimental procedures, and nuances related to TOC analyses.

Appendix $B$ describes the determination of $M A C_{O C}$ values from HPLC-PDA chromatographic data using equations 1-4. Description of the calculation with reported values is given in support of the novel measurement.

Appendix $\mathrm{C}$ describes the calculation of the emission factor (EF) for benzo[a]pyrene (BaP) directly from HPLC-PDA chromatographic data, without use of standards. A short description with reported values is demonstrated. The estimated emission factor for BaP in the sample is 0.352 $\mathrm{mg}_{\text {Bap }} \mathrm{kg}_{\text {fuel }}{ }^{-1}$.

Figure S1 shows the schematic and image of inverted gravity flame reactor (IGFR). In addition, the sequence of diluted flames (left) from low (colder) to high (hotter) temperature depicting variations in flame brightness.

Figure S2 shows the figure of merit reporting the relative accuracy and precision of assigned elemental formulas measured from the QE-HF-X Orbitrap high resolution mass spectrometer (HRMS) acquired in (+/-) APPI and (+/-) ESI mode for the EEF191 sample. Histograms representing normally distributed formula assignments in APPI and ESI are complemented with population statistics, justifying the formula assignments.

Figure S3 illustrates the hydrogen to carbon $(\mathrm{H} / \mathrm{C})$ ratio vs. carbon plot for EEF191 sample. Symbols representative of assigned formulas are color coded to the double bond equivalent (DBE) in combined APPI and ESI modes of detection. The symbol size is proportional to the logarithm of the peak intensity corresponding to the detected ion.

Figure S4 shows the background-subtracted LC-PDA chromatograms of all ethane fuel combustion samples at various dilutions of the flame in IGFR experiments from EEF196 -EEF192.

Figure S5 Upper panel: 3D LC-PDA chromatogram of OC fraction extracted from PM sample collected in EEF 196 experiment (0\% dilution). Lower panels: Individual absorbance spectra of 7 selected $\mathrm{BrC}$ chromophores with assigned elemental formulas, corresponding DBE and Al values, and examples of their possible structures. Structural assignment was made possible via correlative assessment of LC-PDA retention time with extracted ion chromatogram from MS detector.

Figure $\mathrm{S} 6$ shows the histograms in logarithmic scale of oxygen to carbon $(\mathrm{O} / \mathrm{C})$ ratio for individually assigned species in all samples (EEF191-EEF196) detected in APPI-HRMS, binned to the sum of MS peak intensity. The bin width is 0.02 for all datasets.

Figure $\mathrm{S} 7$ shows the relative contribution of the $\sim 25$ most absorbing $\mathrm{BrC}$ species detected in five PM samples collected in the ethane flame experiments (EEF196-EEF192), with respect to the total MACoc absorption determined by each of the samples following the method in Appendix A, respectively.

Figure $\mathrm{S} 8$ shows the $M A C_{0 c}$ and their corresponding Angstrom Absorption Exponent (AAE) values in each of the samples (EEF196-EEF192). The AAE in this study was determined by taking a fit through the data of $\ln \left(\mathrm{MAC}_{\mathrm{oc}}\right) \mathrm{vs} \ln (\lambda)$ at specific wavelength ranges of each of the samples to which there are nonzero absorbance/MAC $(\lambda)$ values. 
Figure S9 illustrates graphical representation of the optical-based $\mathrm{BrC}$ classes in $\log \left(\mathrm{MAC}_{405 \mathrm{~nm}}\right)$-AAE space extrapolated from $\mathrm{MAC}_{550 \mathrm{~nm}}$ in previous report. $\mathrm{BrC}$ classes are grouped according to their optical and physicochemical properties within 5 general classes of $\mathrm{BrC}$ and $\mathrm{BC}$. Shaded regions represent very weakly absorbing $\mathrm{BrC}(\mathrm{VW}-\mathrm{BrC})$, weakly absorbing $\mathrm{BrC}(\mathrm{W}-\mathrm{BrC})$, moderately absorbing $\mathrm{BrC}(\mathrm{M}-\mathrm{BrC})$, strongly absorbing $\mathrm{BrC}(\mathrm{S}-\mathrm{BrC})$ and black carbon $(\mathrm{BC})$.

Table S1 summarizes tabulated values of 25 major BrC chromophores according to LC retention times (RT), UV-visible spectra, assigned elemental formulas, probable structures of the major BrC chromophores, experimental $\mathrm{m} / \mathrm{z}$, error, DBE, and detection modes. References of previous reports of UV-visible spectra and LC-HRMS analysis justify plausible assignment of BrC chromophores. All detected compounds are reported as neutral species. 
Appendix A. Particulate Matter (PM) Sampling Information, TOC Analysis

For TOC analysis, PM samples were collected on fiberglass filters (934-AH 47mm, SterliTech, Kent, WA, USA) instead of PTFE filters. A weighed filter was placed in an open-face filter holder downstream of the flame. The sampling flow rate was set at $4 \mathrm{slpm}$, which was higher than the inlet flow, to ensure that all PM from the flame was collected. The total mass of the collected sample was used in the calculation of soot yield. Makeup air compensated for the difference in inlet and sampling flow rates. ${ }^{1}$ Based on the $37 \mathrm{~mm}$ diameter of the open filter, the face velocity is approximately $6 \mathrm{~cm} / \mathrm{s}$. The sampling time typically varied from $5 \mathrm{~min}$ to $120 \mathrm{~min}$, depending on the fuel dilution ratio. The temperature and the relative humidity at the filter face vary between the different experiments depending on the fuel dilution and the amount of makeup air. The OC data reported is uncorrected for sampling artifacts due to the ambiguity associated with correction for sampling artifacts in this complex samples sampling environment.

In sampling carbonaceous aerosols, significant adsorption of gas-phase organic compounds is associated with PM sampling on quartz fiber filters. Turpin et al. showed the placing the Teflon filter in front of a quartz filter can reduce the positive artifacts. ${ }^{2}$ Literature also suggests that filter artifacts could be eliminated by the use of a denuder. ${ }^{3,4}$ In our experiments, however, the denuder was not used due to two principle concerns. (i) The samples were collected the reactor exit with temperatures exceeding $80^{\circ} \mathrm{C}$ in some cases, which potentially would damage the denuder. (ii) Particle losses in the denuder was another consideration. As the sample was taken directly downstream of the flame, these particles had higher charges than typical environmental aerosols. At the lower flow rates, we observed particle deposition on the walls of the reactor, thus to ensure the collection of all the particles from the flame, the sampling flow was kept higher than the inlet flow required for calculation of the soot yields normalized by the total fuel flow. A loss of the highly charged particles on the denuder surfaces due to electrostatic forces, especially at a relatively low flow rates, was previously seen in the engine exhaust measurements. ${ }^{5,6}$ Future work can address the balance between the potential particle loss, flow rates, and sample dilution characterizing the effects of sampling parameters on the total OC/EC production from these flames. 
The mass absorption coefficient (MACoc) for the extracted OC mixture(s) was quantified experimentally from HPLC-PDA chromatographic data using the following equations:

$\operatorname{Mass}_{i n j}(g)=\frac{\operatorname{massoC}_{\text {O }}(g)}{V_{\text {soln }}} \cdot V_{i n j}$

$V_{\text {elution }}\left(m^{3}\right)=F \cdot \Delta t \cdot 10^{-6}$

$C_{\text {mass }}=\frac{\operatorname{Mass}_{\text {inj }}(g)}{V_{\text {elution }}\left(m^{3}\right)}$

$M A C_{O C}(\lambda)=\frac{A_{10}^{\text {solution }}(\lambda) \ln (10)}{b C_{\text {mass }}}$

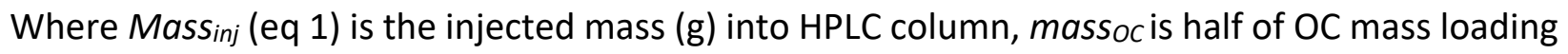
reported in Table 1 in main text (as only half of the mixture was measured), $V_{\text {soln }}$ and $V_{i n j}$ are the volume of the reconstituted solution (300uL) and injection (25uL) into LC, respectively. From there, the elution volume of the entire analytical separation $\left(V_{\text {elution, }} \mathrm{m}^{3}\right)$ from eq. 2 is calculated where $F$ is the LC flow rate $\left(0.2 \mathrm{~mL} \mathrm{~min}^{-1}\right)$ and $\Delta t$ is the LC elution time range (91 min). $C_{\text {mass }}$ (eq. 3 ) given in units of $\mathrm{g} \mathrm{m}^{-3}$ is determined by dividing Massinj and $V_{\text {elution }}$ from eq. $1 \& 2$. Subsequently the value for $C_{\text {mass }}$ (eq. 3 ) is incorporated into eq.4 to solve for $M A C_{o c}$ where $A_{10}^{\text {solution }}(\lambda)$ is the base-10 absorption averaged across LC separation and $b$ is the optical pathlength $(\mathrm{m})$ of the flow cell. As an example, the MACOC at $300 \mathrm{~nm}$ for EEF196 sample is $1.17 \mathrm{~m}^{2} \mathrm{~g}^{-1}$ given the bulk absorption $(300 \mathrm{~nm})$ of the entire elution time window (0-91 $\mathrm{min})$ is $9.38 \times 10^{-4} \mathrm{~A}$.U. This analytical method is novel approach to quantify the mass normalized absorption cross-section representative of bulk absorption of the solution, directly from the integration of HPLC-PDA chromatographic data. 
The calculated amount of benzo[a]pyrene (BaP) in the EEF196 sample (0\% dilution; $T_{\max } \sim 1946.5$ $K)$ is achieved using equation (1) to determine injected mass $m_{o}$ and quantify organic compounds from HPLC-PDA chromatographic data.

$$
m_{o}=\frac{A b s(\lambda) \cdot F \cdot \Delta t \cdot M W}{b \cdot \varepsilon}
$$

Where $F$ is the LC flow rate $\left(\mathrm{mL} \mathrm{min}^{-1}\right), b(\mathrm{~cm})$ is the optical pathlength of the PDA flow cell, $A b s(\lambda)$ is the absorbance at specified wavelength for the specific integrated peak, $M W$ is the molecular weight of analyte $\left(\mathrm{g} \mathrm{mol}^{-1}\right), \Delta t$ is the LC elution time range for integrated peak ( $\# 20$ in case of $\mathrm{BaP}$ ), and $\varepsilon$ is the molar extinction coefficient. The absorbance at $384 \mathrm{~nm}$ from HPLC-PDA detector is $9.83 \times 10^{-4}$ A.U., corresponding to chromophore $\# 20$ with molecular weight (MW), $252.21 \mathrm{~g} \mathrm{~mol}^{-1}$. From this equation, the injected mass ( $\mathrm{m}_{0}$ ) into LC ( $25 \mathrm{uL}$ volume) is obtained to be $14.35 \mathrm{ng} \mathrm{BaP}$. The mass in the reconstituted solution (300uL) as well as total amount in the filter extract is then divided by mass of fuel consumed $(\mathrm{g})$ to obtain the emission factor $\left(\mathrm{mg} \mathrm{kg}^{-1}\right)$. The emission factor for $\mathrm{BaP}$ is $0.352 \mathrm{mg}_{\mathrm{BaP}} \mathrm{kg}_{\text {fuel }}{ }^{-1}$. 


\section{Supplemental Figures}

(a)

Inverted Gravity Flame Reactor (IGFR)

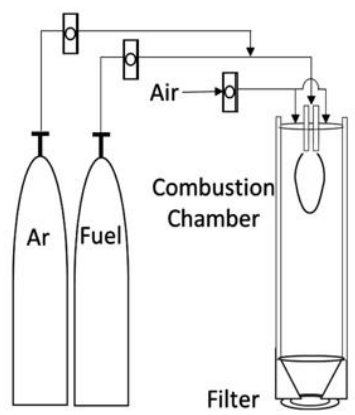

(b)

Colder Temperature

Hotter Temperature

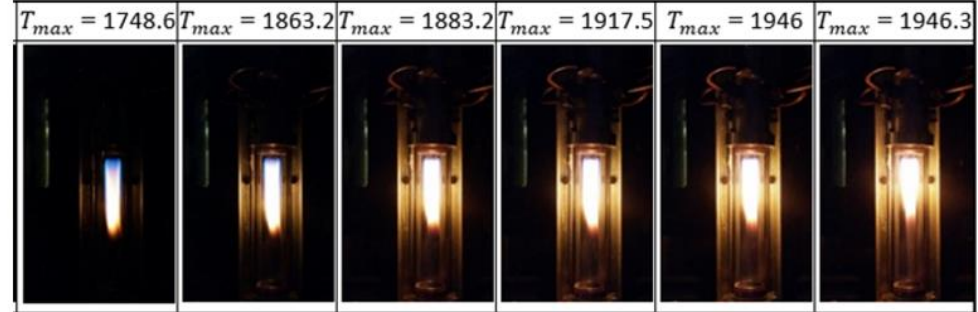

Figure S1: (a) Schematic and image of inverted gravity flame reactor (IGFR) (right). (b) Sequence of diluted flames (left) from low (colder) to high (hotter) temperature depicting variations in flame brightness.

a)

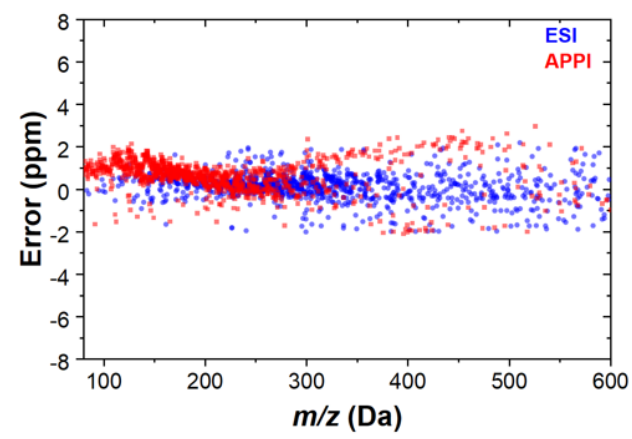

b)

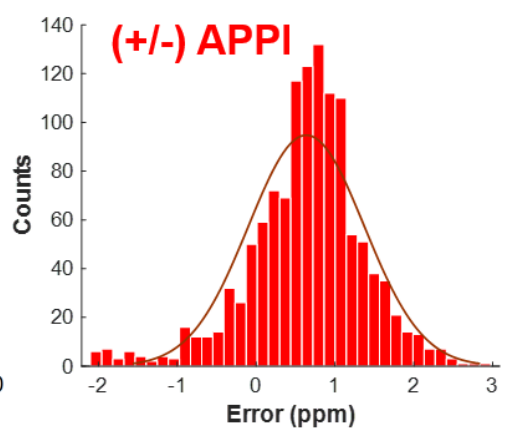

c)

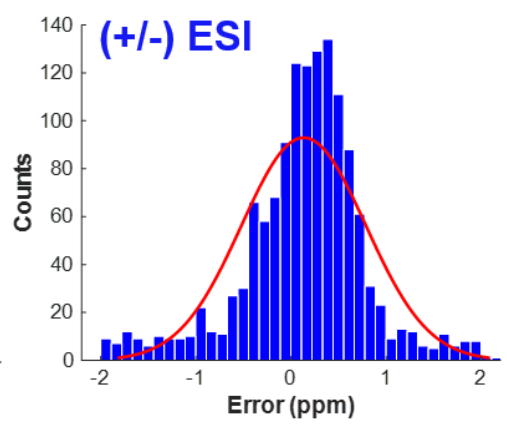

Figure S2: (a) Figure of merit showing the accuracy of assigned elemental formulas via direct infusion (+/) ESI/APPI-HRMS detection (combined) on QE-HF-X Orbitrap ${ }^{T M}$ (Thermo, USA). Assigned formulas in ESI data is color coded in blue while APPI data in red. Histograms (b) and (c) represent normally distributed formula assignments in APPI and ESI with the average mean and standard deviation $(\mu \pm \sigma)$ of $0.636 \pm$ 0.74 ppm and $0.132 \pm 0.65$ ppm, respectively. 


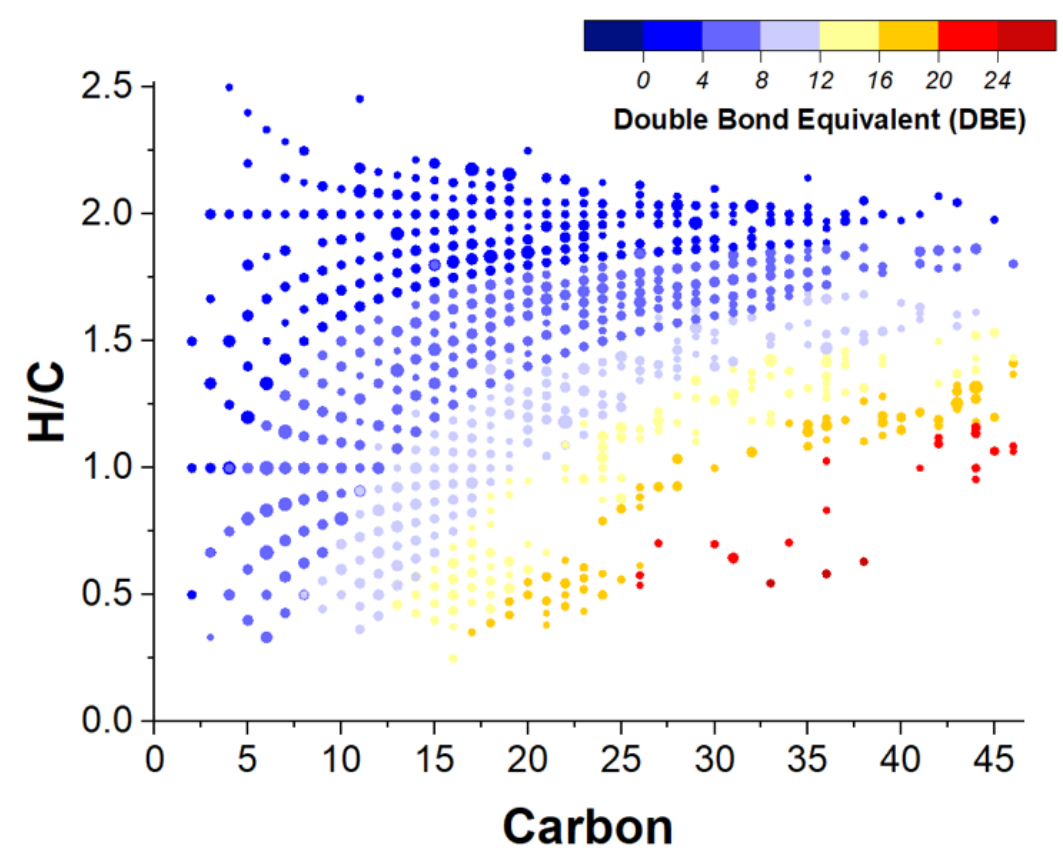

Figure S3: Hydrogen to carbon (H/C) ratio vs. carbon plot for EEF191 (80\% Dilution) sample. Symbols are color coded to the double bond equivalent (DBE) of assigned neutral formulas in both APPI and ESI modes. The symbol size is proportional to the logarithm of the peak intensity corresponding to the detected ion.

All potential $\mathrm{BrC}$ organic compounds in $\mathrm{H} / \mathrm{C}$ vs. carbon plot exhibit a double bond equivalent (DBE) value greater than 7 and $\mathrm{H} / \mathrm{C}<1$ (light blue to dark red color). Species with low DBE (DBE $<$ 7) and $\mathrm{H} / \mathrm{C}>1$ are compounds with little to no conjugation of $\pi$ bonds, therefore are not prominent $\mathrm{BrC}$ absorbers. Organic compounds with $\mathrm{H} / \mathrm{C}>1.5$ (blue and dark blue color) are aliphatic hydrocarbons. Those species do not absorb within $\mathrm{BrC}$ absorption in this study.

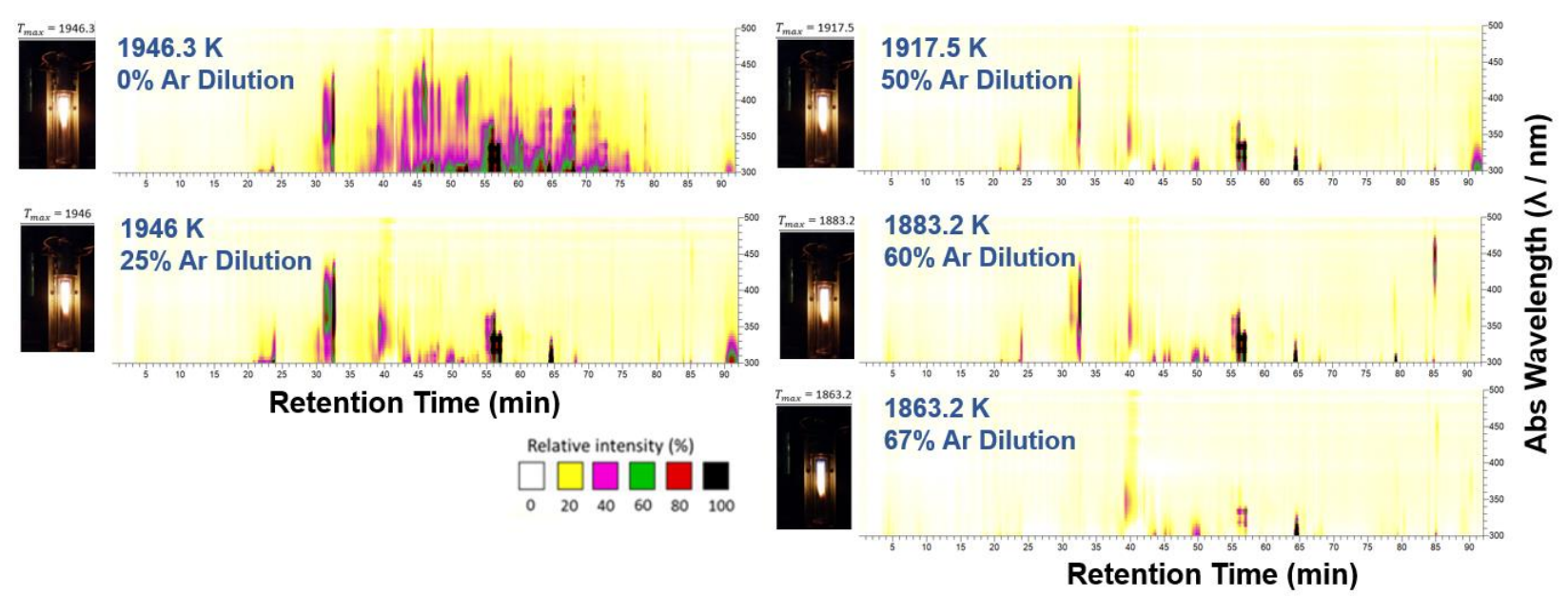

Figure S4: Background-subtracted LC-PDA chromatograms representing ethane fuel combustion samples at various dilutions of the flame in IGFR experiments. The $x$-axis is retention time, the $y$-axis is the UV-vis absorption wavelength and color denotes the absorbance intensity recorded by the PDA detector. Images of combustion chamber are shown to correlate flame brightness with temperature. 


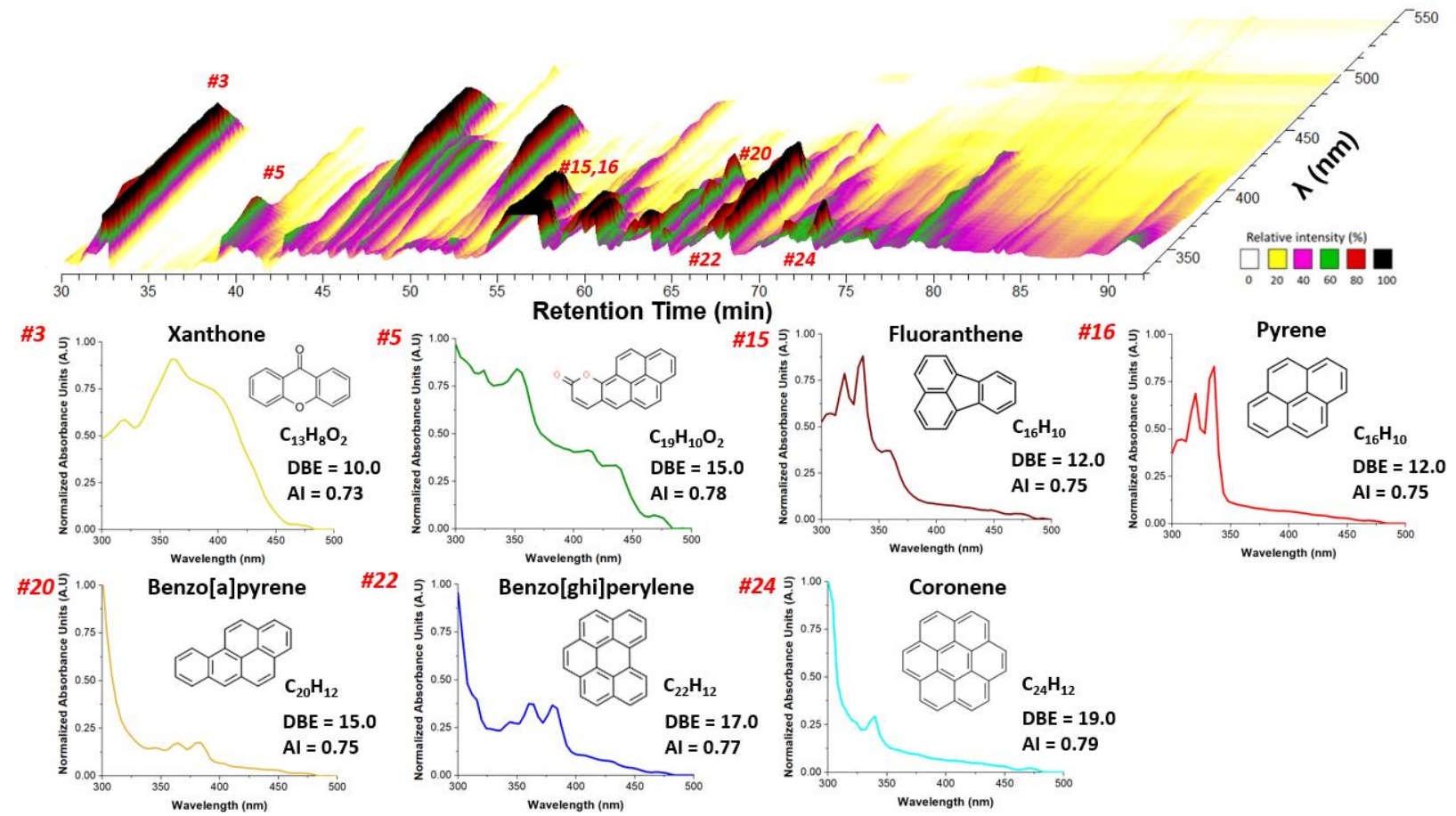

Figure S5: Upper panel: 3D LC-PDA chromatogram of OC fraction extracted from PM sample collected in EEF 196 experiment (O\% dilution). Lower panels: Individual absorbance spectra of 7 selected $\mathrm{BrC}$ chromophores with assigned elemental formulas, corresponding DBE and AI values, and examples of their possible structures.
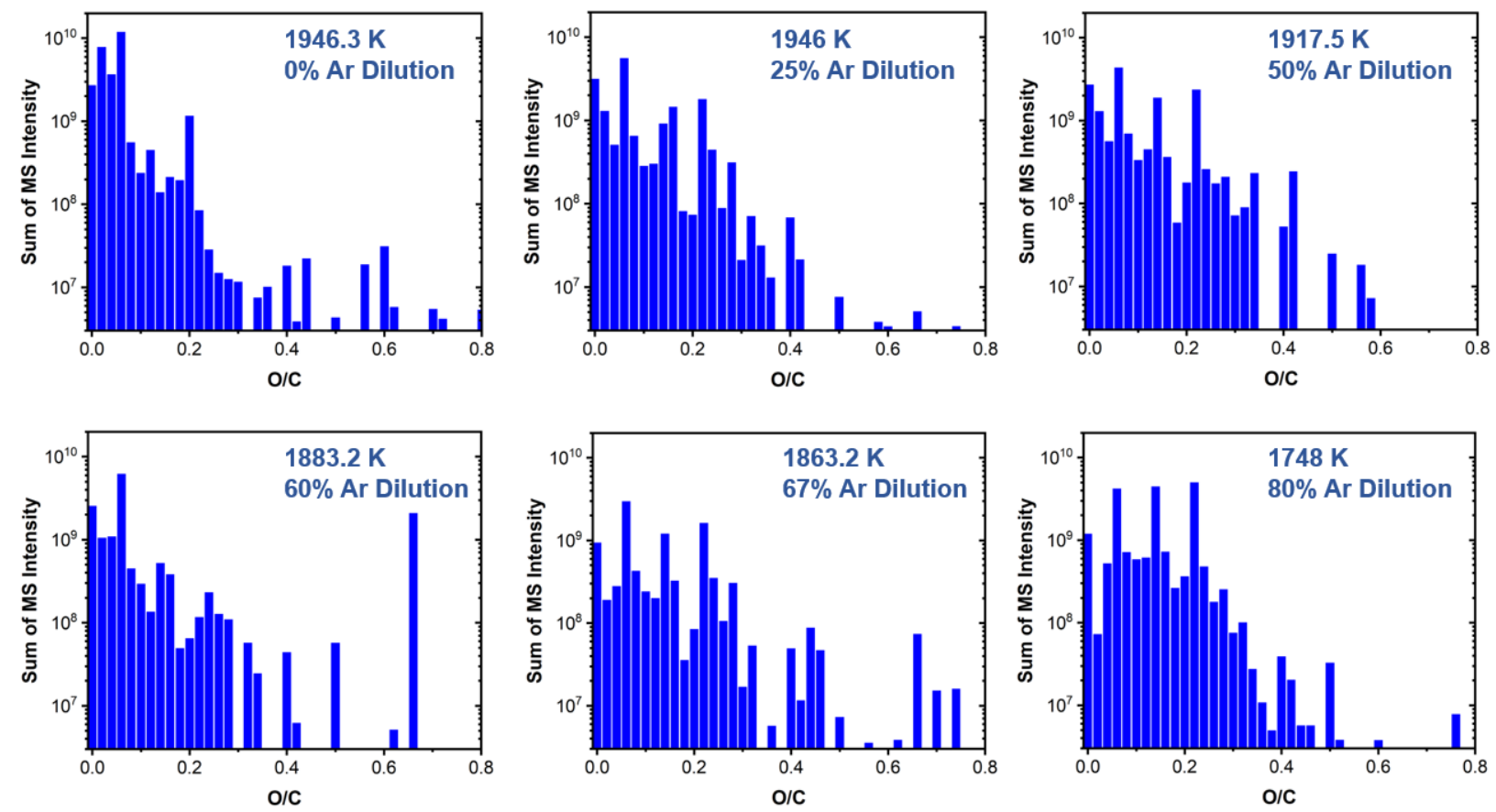

Figure S6: Histogram of oxygen to carbon $(\mathrm{O} / \mathrm{C})$ ratio for individually assigned species binned to the sum of MS peak intensity. 



Figure S7: Relative contribution of the 25 most absorbing BrC species detected in five PM samples collected in the ethane flame experiments (EEF196-EEF192), with respect to the total BrC absorption determined by each of the samples, respectively.

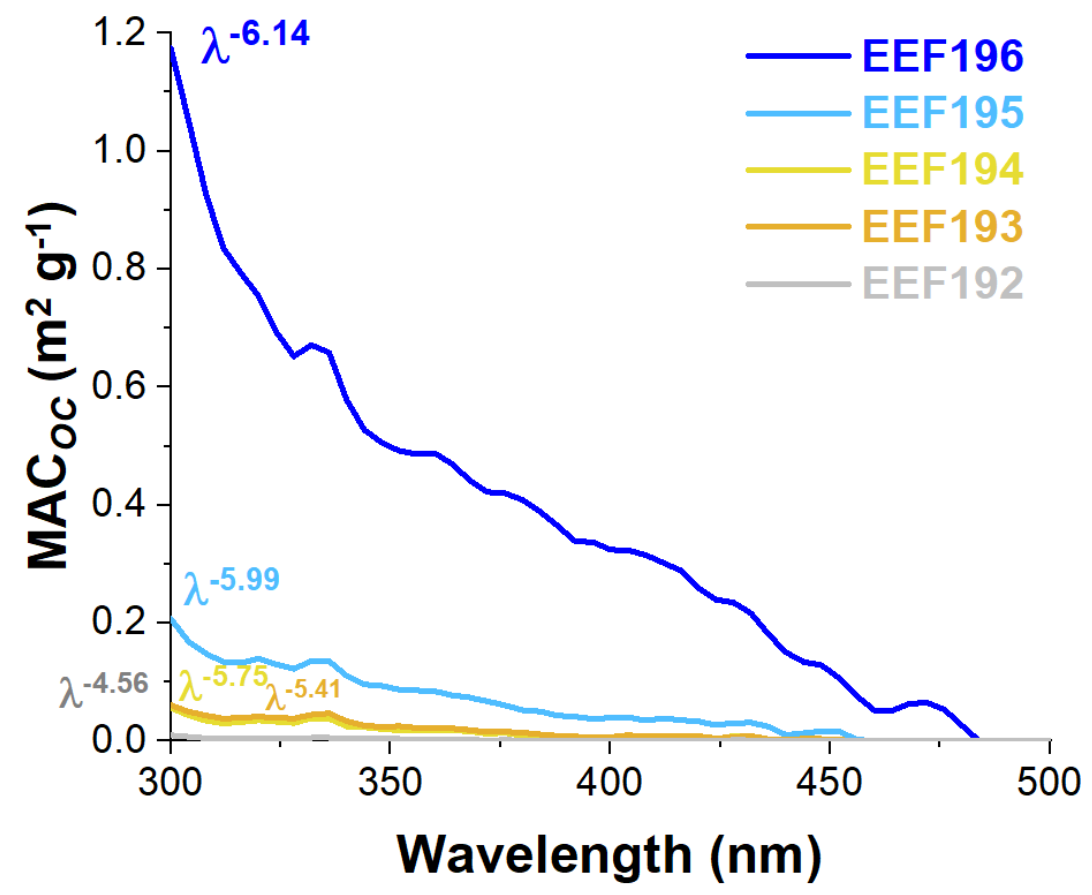

Figure S8: (a) Mass absorption coefficient (MAC) spectra of all BrC samples (EEF196-EEF192) examined in this study 
The AAE in this study was determined by taking a fit through the data of $\ln \left(M A C_{O C}\right)$ vs $\ln (\lambda)$ at specific wavelength ranges of each of the samples to which there are nonzero absorbance/MAC $(\lambda)$ values. The $M A C_{\text {bulk }}$ measured at $\lambda_{350 \mathrm{~nm}}$ for EEF196 sample is $0.49 \mathrm{~m}^{2} \mathrm{~g}^{-1}$, and is significantly lower than $M A C_{B r C}$ (brown line in main text, Figure $6 \mathrm{~b}$ ) in previous study ${ }^{7}$, which measured $7.23 \mathrm{~m}^{2} \mathrm{~g}^{-1}$ at similar wavelength. The mean refractive index (k) obtained in their study ${ }^{7}$ was converted to $\mathrm{MAC}_{\text {bulk value }}{ }^{8}$ assuming estimated physical density of carbon atoms for optically measured carbon spheres, $1.6 \mathrm{~g} \mathrm{~cm}^{-1}$. The measured AAE for $\mathrm{BrC}_{\text {spheres }}$ in previous study ${ }^{7}$ was 1.5, substantially lower than $\operatorname{BrC}$ from biomass burning. The low AAE in their study ${ }^{7}$ is likely attributable more particle-like morphology than dissolved $\mathrm{BrC}$.

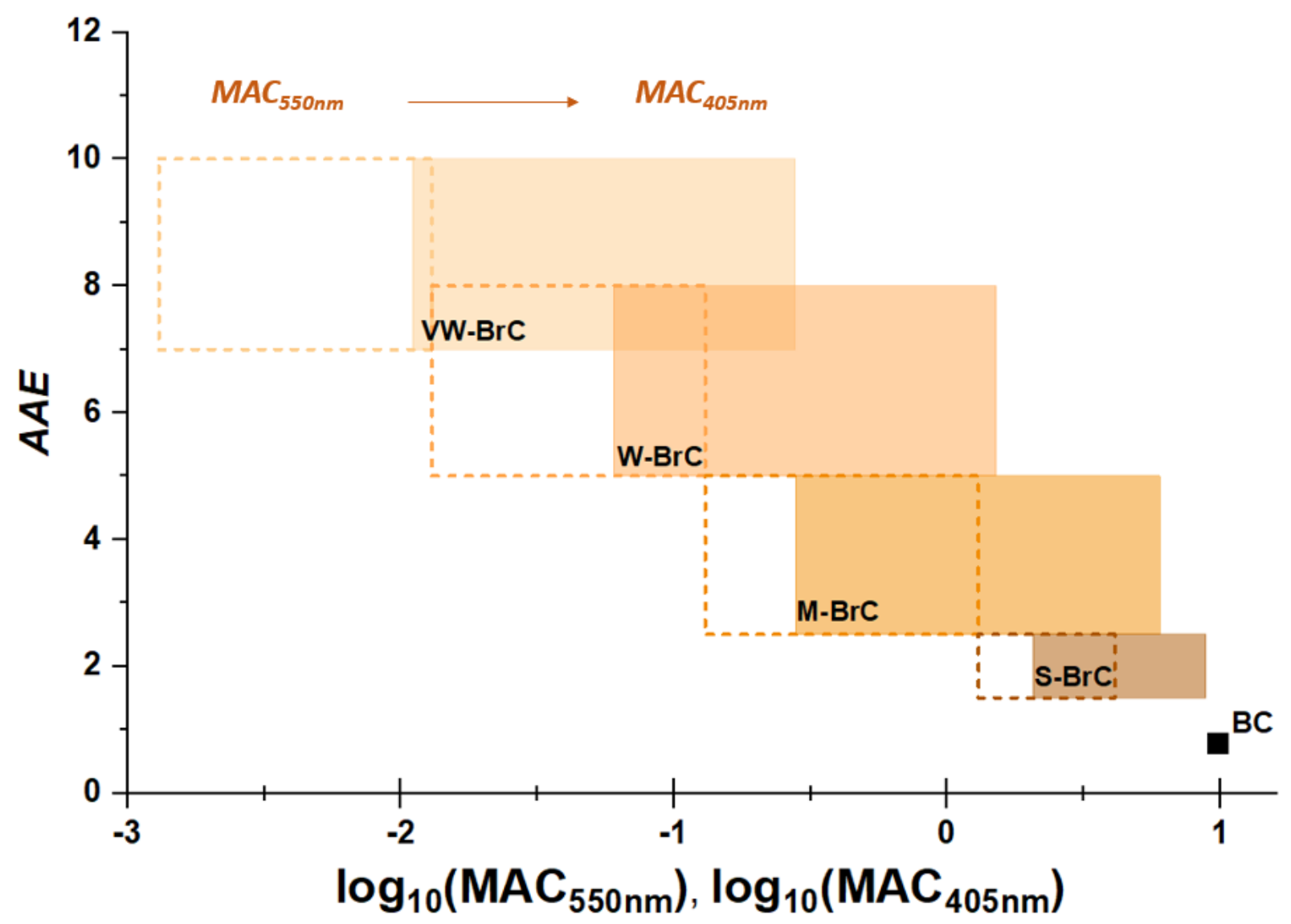

Figure S9: Graphical representation of the optical-based $B r C$ classes in $M^{A} C_{405 n m}$-W space converted from $k_{550 \mathrm{~nm}}$ in previous report ${ }^{9} \mathrm{BrC}$ classes are grouped according to their optical and physicochemical properties within 4 general classes of $B r C$ and $B C$. Shaded regions represent very weakly absorbing $B r C(V W-B r C)$, weakly absorbing $\operatorname{BrC}(W-B r C)$, moderately absorbing $\operatorname{BrC}(M-B r C)$, strongly absorbing $\operatorname{BrC}(S-B r C)$ and black carbon (BC).

The four $\mathrm{BrC}$ classes are defined by the $\mathrm{MAC}_{550}$ and $\mathrm{AAE} \sim w+1$ threshold values summarized in Table 1 of Saleh 2020. ${ }^{9}$ 
Table S1: LC retention times (RT), PDA spectra, assigned elemental formulas, probable structures of the major $\mathrm{BrC}$ chromophores, experimental $\mathrm{m} / \mathrm{z}$, error, $\mathrm{DBE}$, and detection mode are noted. For clarity, all detected compounds are reported as neutral species.

\begin{tabular}{|c|c|c|c|c|c|c|c|}
\hline \multirow{2}{*}{$\begin{array}{l}\text { Peak \# } \\
{[R T} \\
(\min )]\end{array}$} & \multirow[t]{2}{*}{ UV-Vis spectrum } & \multicolumn{2}{|c|}{ Experimental m/z } & \multirow{2}{*}{$\begin{array}{l}\text { Neutral } \\
\text { Formula }\end{array}$} & \multirow[t]{2}{*}{$D B E$} & \multirow{2}{*}{$\begin{array}{l}\text { Error } \\
\text { (ppm) }\end{array}$} & \multirow{2}{*}{$\begin{array}{c}\text { Examples of Possible } \\
\text { Structures }\end{array}$} \\
\hline & & APPI(-) & APPI(+) & & & & \\
\hline $\begin{array}{l}\# 1 \\
21.16- \\
22.83\end{array}$ & (10) & & & & & & Unassigned Chromophore \\
\hline $\begin{array}{l}\# 2 \\
23.10- \\
23.97\end{array}$ & 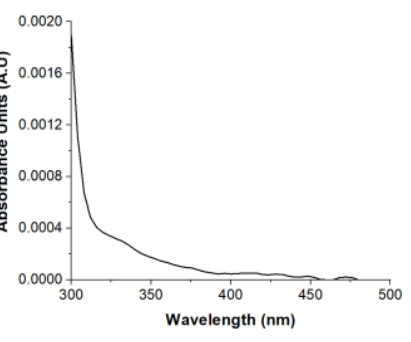 & & & & & & Unassigned Chromophore \\
\hline \multirow[t]{4}{*}{$\begin{array}{l}\# 3 \\
31.08- \\
31.93\end{array}$} & \multirow{4}{*}{ 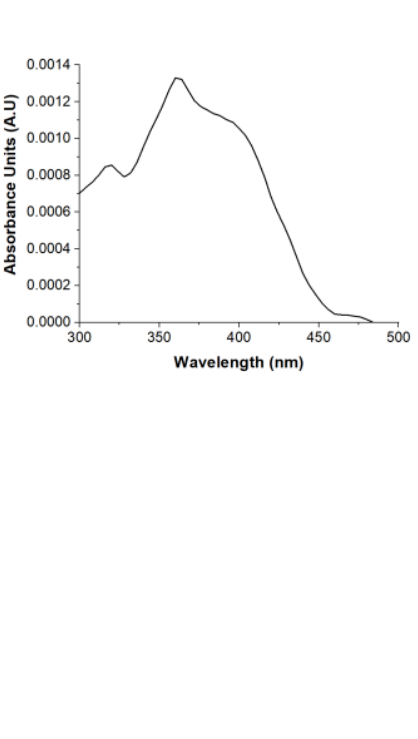 } & & 197.0596 & $\mathrm{C}_{13} \mathrm{H}_{8} \mathrm{O}_{2}$ & 10.0 & 0.234 & $\begin{array}{l}\text { Xanthone based on } \\
\text { literature reports }{ }^{10,11} \text { and } \\
\text { UV-visible spectrum }\end{array}$ \\
\hline & & & 198.0674 & $\mathrm{C}_{13} \mathrm{H}_{10} \mathrm{O}_{2}$ & 9.0 & 0.510 & $\begin{array}{l}\text { Characteristic UV-Vis } \\
\text { spectrum with extended } \\
\text { absorption }>320 n m \text { and } \\
\text { based on literature } e^{12}\end{array}$ \\
\hline & & & 181.0644 & $\mathrm{C}_{13} \mathrm{H}_{8} \mathrm{O}$ & 10.0 & 1.665 & $\begin{array}{l}\text { 9-Fluorenone based on } \\
\text { literature reports }\end{array}$ \\
\hline & & 195.0450 & & $\mathrm{C}_{13} \mathrm{H}_{10} \mathrm{O}_{2}$ & 10.0 & 0.783 & \\
\hline \multirow{3}{*}{$\begin{array}{l}\# 4 \\
32.31- \\
32.85\end{array}$} & & & 197.0596 & $\mathrm{C}_{13} \mathrm{H}_{8} \mathrm{O}_{2}$ & 10.0 & 0.234 & \\
\hline & & & 198.0674 & $\mathrm{C}_{13} \mathrm{H}_{10} \mathrm{O}_{2}$ & 9.0 & 0.510 & \\
\hline & & & 181.0644 & $\mathrm{C}_{13} \mathrm{H}_{8} \mathrm{O}$ & 10.0 & 1.665 & \\
\hline
\end{tabular}




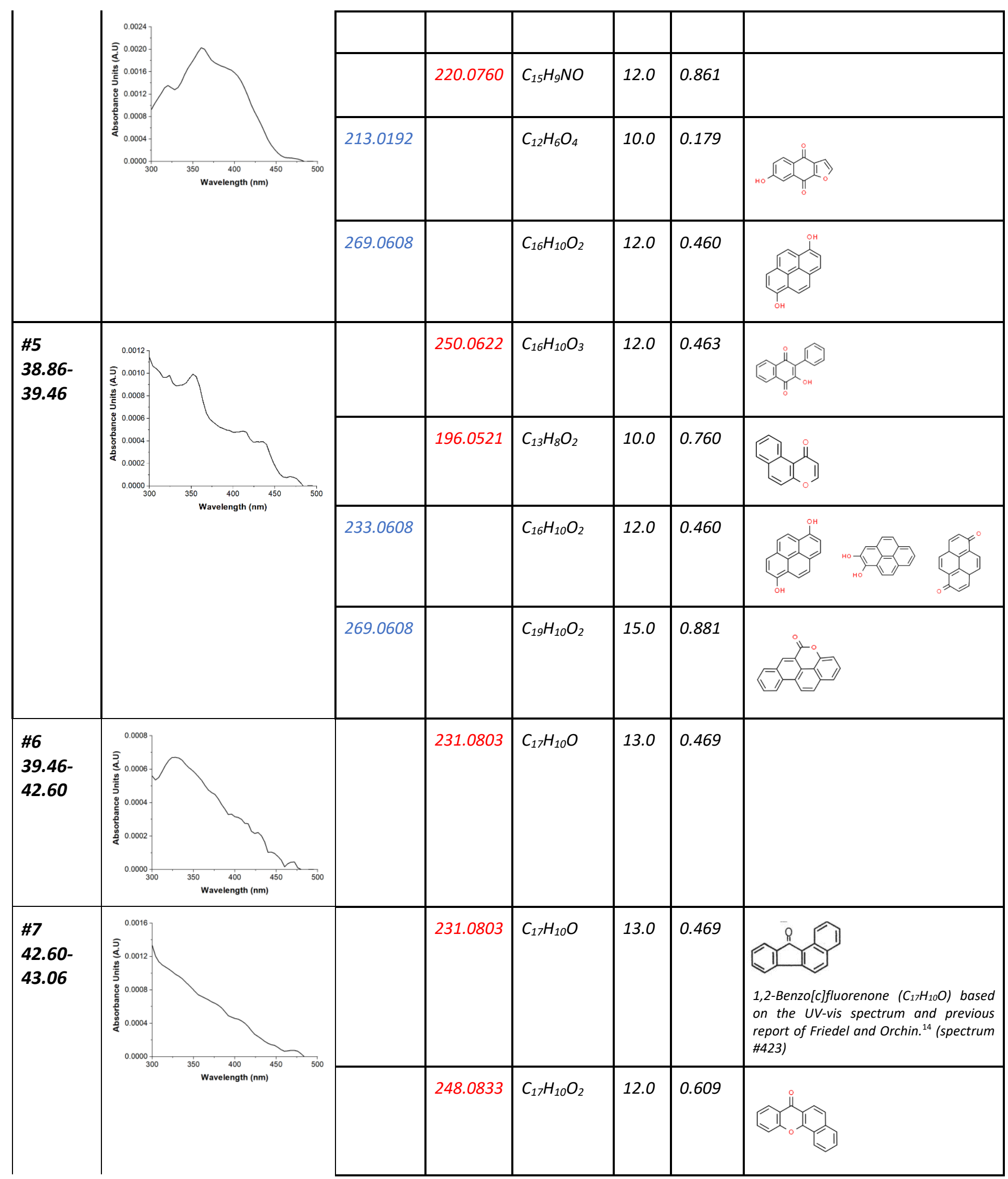









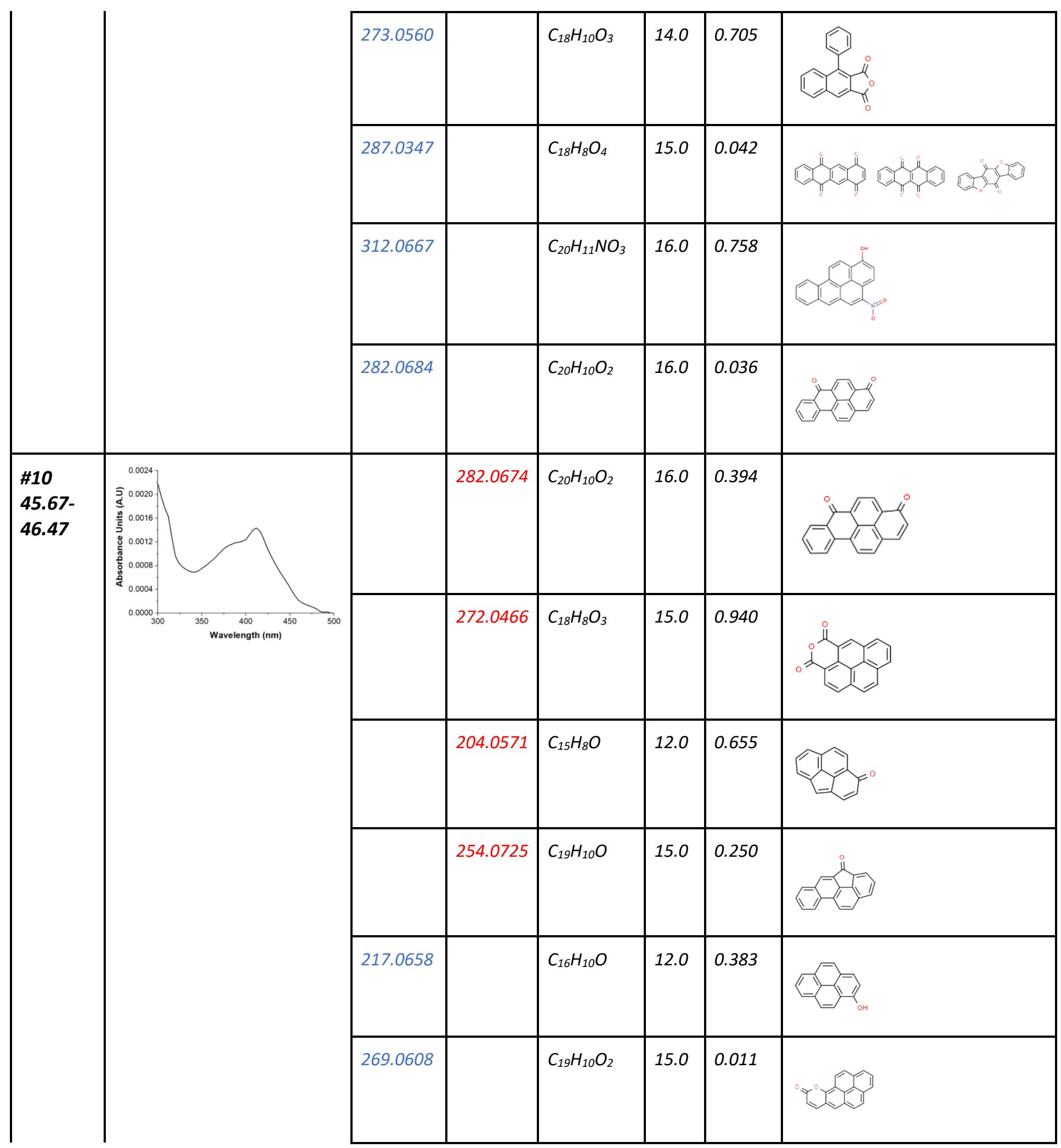




\begin{tabular}{|c|c|c|c|c|c|c|c|}
\hline & & 294.0925 & & $\mathrm{C}_{21} \mathrm{H}_{13} \mathrm{NO}$ & 16.0 & 0.145 & \\
\hline & & 287.0347 & & $\mathrm{C}_{18} \mathrm{H}_{8} \mathrm{O}_{4}$ & 15.0 & 0.112 & \\
\hline & & 312.0667 & & $\mathrm{C}_{20} \mathrm{H}_{11} \mathrm{NO}_{3}$ & 16.0 & 0.364 & \\
\hline \multirow{9}{*}{$\begin{array}{l}\# 11 \\
46.73- \\
47.60\end{array}$} & \multirow{9}{*}{ 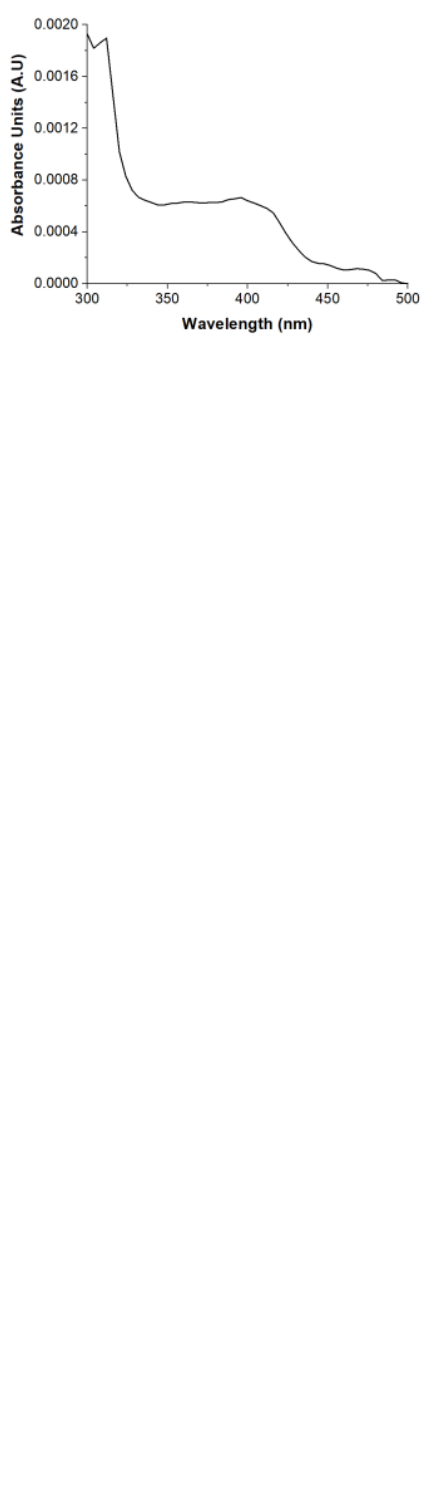 } & & 254.0725 & $\mathrm{C}_{19} \mathrm{H}_{10} \mathrm{O}$ & 15.0 & 0.250 & \\
\hline & & & 248.0832 & $\mathrm{C}_{17} \mathrm{H}_{12} \mathrm{O}_{2}$ & 12.0 & 0.690 & \\
\hline & & & 231.0808 & $\mathrm{C}_{17} \mathrm{H}_{10} \mathrm{O}$ & 13.0 & 1.508 & \\
\hline & & & 222.0675 & $\mathrm{C}_{15} \mathrm{H}_{10} \mathrm{O}_{2}$ & 11.0 & 0.355 & \\
\hline & & & 220.0675 & $\mathrm{C}_{15} \mathrm{H}_{8} \mathrm{O}_{2}$ & 12.0 & 0.586 & \\
\hline & & & 204.0571 & $\mathrm{C}_{15} \mathrm{H}_{8} \mathrm{O}$ & 12.0 & 0.081 & \\
\hline & & & 205.0602 & $\mathrm{C}_{10} \mathrm{H}_{8} \mathrm{~N}_{2} \mathrm{O}_{3}$ & 8.0 & 1.408 & \\
\hline & & 262.0508 & & $\mathrm{C}_{16} \mathrm{H}_{9} \mathrm{NO}_{3}$ & 13.0 & 0.243 & \\
\hline & & 241.0660 & & $\mathrm{C}_{18} \mathrm{H}_{10} \mathrm{O}$ & 14.0 & 0.256 & \\
\hline
\end{tabular}




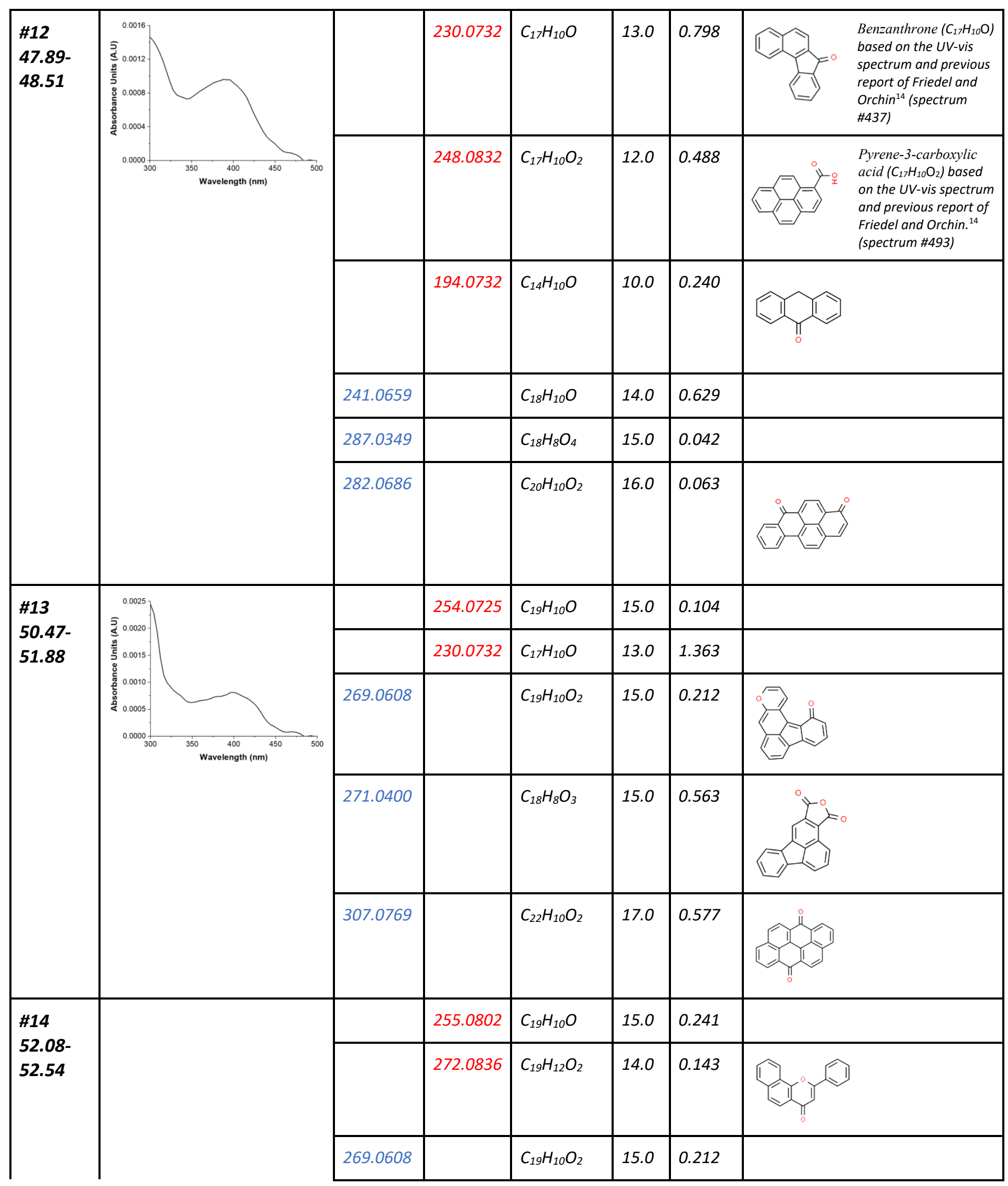




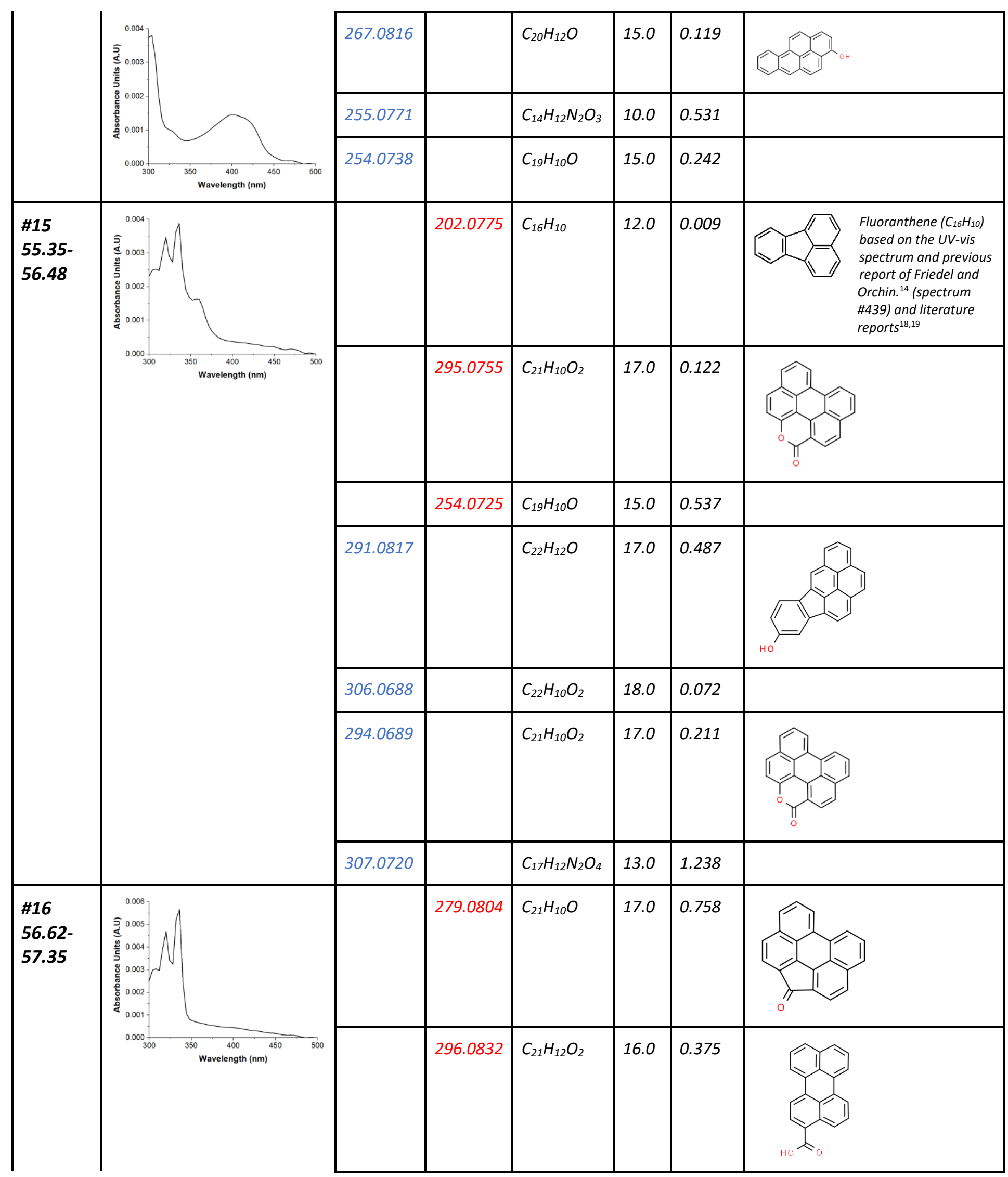




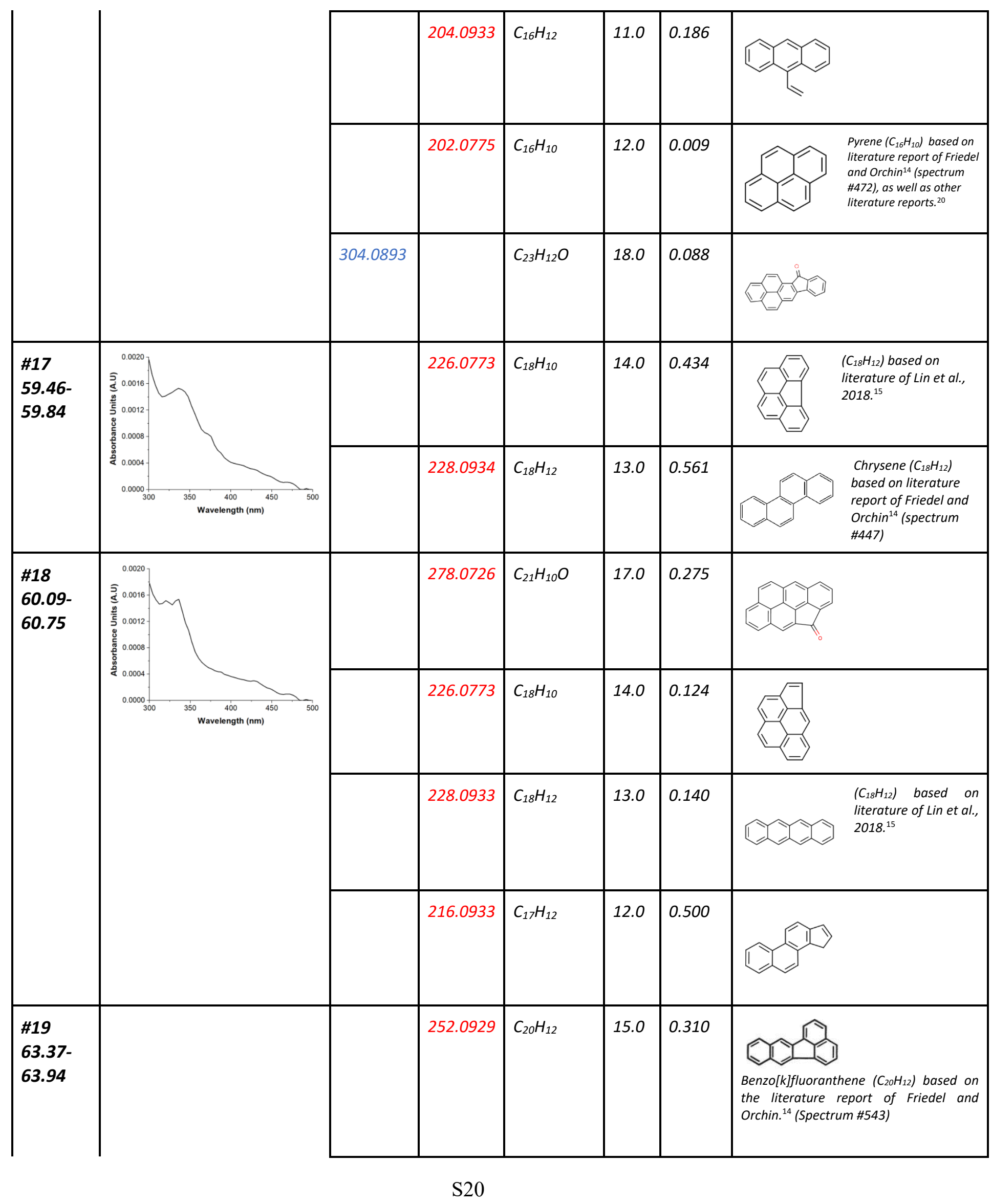




\begin{tabular}{|c|c|c|c|c|c|c|c|}
\hline & 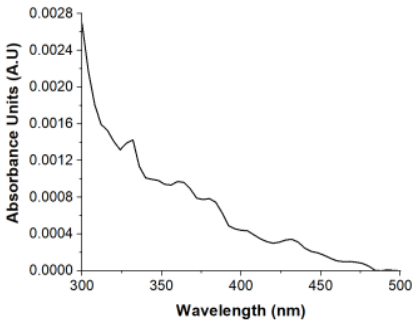 & & 294.0677 & $\mathrm{C}_{21} \mathrm{H}_{10} \mathrm{O}_{2}$ & 17.0 & 0.234 & $\begin{array}{l}\left(\mathrm{C}_{21} \mathrm{H}_{10} \mathrm{O}_{2}\right) \text { based on } \\
\text { the literature report } \\
\text { of Lin et al., 2018. } .^{15}\end{array}$ \\
\hline \multirow[t]{2}{*}{$\begin{array}{l}\# 20 \\
64.12- \\
64.90\end{array}$} & \multirow{2}{*}{ 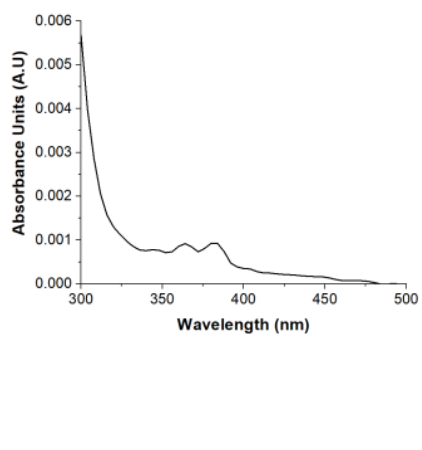 } & & 252.0929 & $\mathrm{C}_{20} \mathrm{H}_{12}$ & 15.0 & 0.310 & $\begin{array}{l}\text { Benzo[a]pyrene } \\
\left(\mathrm{C}_{20} \mathrm{H}_{12}\right) \text { based on } \\
\text { the literature } \\
\text { report of Friedel } \\
\text { and Orchin }{ }^{14} \\
\text { (Spectrum \#554) }\end{array}$ \\
\hline & & & 253.0969 & $\mathrm{C}_{15} \mathrm{H}_{12} \mathrm{~N}_{2} \mathrm{O}_{2}$ & 11.0 & 1.083 & \\
\hline \multirow[t]{4}{*}{$\begin{array}{l}\# 21 \\
66.90- \\
67.60\end{array}$} & \multirow{4}{*}{ (2) } & & 276.0931 & $\mathrm{C}_{22} \mathrm{H}_{12}$ & 17.0 & 0.587 & $\begin{array}{l}\text { Indeno } \\
{[1,2,3 \text { cd]pyrene }} \\
\left(C_{22} H_{12}\right) \text { based on the } \\
\text { UV-vis spectrum and } \\
\text { previous report of } \\
\text { Bagley et al., } 2011 .^{21}\end{array}$ \\
\hline & & & 302.0732 & $\mathrm{C}_{23} \mathrm{H}_{10} \mathrm{O}$ & 19.0 & 1.048 & \\
\hline & & 328.0893 & & $\mathrm{C}_{25} \mathrm{H}_{12} \mathrm{O}$ & 20.0 & 0.224 & \\
\hline & & 302.0735 & & $\mathrm{C}_{23} \mathrm{H}_{10} \mathrm{O}$ & 18.0 & 0.507 & \\
\hline \multirow[t]{2}{*}{$\begin{array}{l}\# 22 \\
67.71- \\
68.43\end{array}$} & \multirow{2}{*}{ (150 } & & 276.0931 & $\mathrm{C}_{22} \mathrm{H}_{12}$ & 17.0 & 0.587 & $\begin{array}{l}\text { Benzo[ghi]perylene } \\
\left(\mathrm{C}_{22} \mathrm{H}_{12}\right) \text { based on the } \\
\text { UV-vis spectrum and } \\
\text { previous report of } \\
\text { Friedel and Orchin. } \\
\text { (spectrum \#567) }\end{array}$ \\
\hline & & & 308.1553 & $\mathrm{C}_{24} \mathrm{H}_{20}$ & 15.0 & 0.526 & $\begin{array}{l}\text { Octahydrocoronene } \\
\left(C_{24} H_{20}\right) \text { based on } \\
\text { characteristic } \\
\text { features of UV-vis } \\
\text { spectrum and } \\
\text { previous report of } \\
\text { Friedel and Orchin. }{ }^{14} \\
\text { (spectrum \#479) }\end{array}$ \\
\hline
\end{tabular}




\begin{tabular}{|c|c|c|c|c|c|c|c|}
\hline & & 291.0817 & & $\mathrm{C}_{22} \mathrm{H}_{12} \mathrm{O}$ & 17.0 & 0.716 & \\
\hline \multirow[t]{3}{*}{$\begin{array}{l}\# 23 \\
69.34- \\
69.93\end{array}$} & \multirow[t]{3}{*}{ 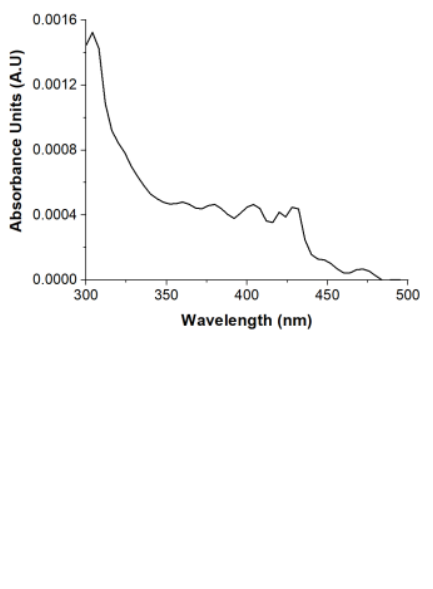 } & & 302.1085 & $\mathrm{C}_{24} \mathrm{H}_{14}$ & 18.0 & 1.019 & $\begin{array}{l}\text { Dibenzo[a, } h] \text { pyrene } \\
\left(C_{24} H_{14}\right) \text { based on } \\
\text { the characteristic } \\
\text { UV-vis spectrum } \\
\text { and previous } \\
\text { report of Friedel } \\
\text { and Orchin. }{ }^{14} \\
\text { (Spectrum \#573) }\end{array}$ \\
\hline & & & 292.0879 & $\mathrm{C}_{22} \mathrm{H}_{12} \mathrm{O}$ & 17.0 & 1.186 & \\
\hline & & & 206.1088 & $\mathrm{C}_{16} \mathrm{H}_{14}$ & 10.0 & 0.621 & \\
\hline $\begin{array}{l}\# 24 \\
72.41- \\
73.26\end{array}$ & 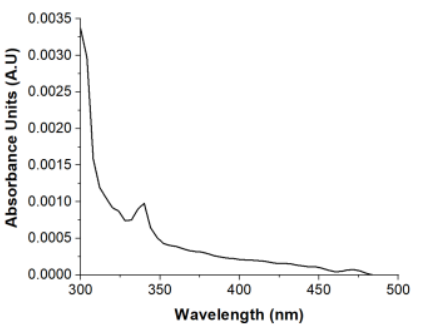 & & 300.093 & $\mathrm{C}_{24} \mathrm{H}_{12}$ & 19.0 & 0.606 & $\begin{array}{l}\text { Coronene }\left(\mathrm{C}_{24} \mathrm{H}_{12}\right) \\
\text { based on the } \\
\text { reference electronic } \\
\text { and measured UV } \\
\text { spectra. }{ }^{21,22} \\
\text { Additional spectra } \\
\text { provided by Friedel } \\
\text { and Orchin. }{ }^{14} \\
\text { (spectrum \#577) }\end{array}$ \\
\hline $\begin{array}{l}\# 25 \\
84.59- \\
85.32\end{array}$ & (1500 & & & & & & Unassigned Chromophore \\
\hline
\end{tabular}




\section{References}

(1) Mahamuni, G. Excitation Emission Matrix Fluorescence Spectroscopy based Sensing of Combustion Generated Particulate Matter. Ph.D., University of Washington, 2020.

(2) Turpin, B.J., J.J. Huntzicker, and S.V. Hering, Investigation of organic aerosol sampling artifacts in the Los Angeles Basin. Atmos. Environ. 1994. 28(19), 3061-3071.

(3) Eatough, D. J.; Wadsworth, A.; Eatough, D. A.; Crawford, J. W.; Hansen, L. D.; Lewis, E. A. A Multiple-System, Multi-Channel Diffusion Denuder Sampler for the Determination of Fine Particulate Organic Material in the Atmosphere. Atmospheric Environ. Part Gen. Top. 1993, 27 (8), 1213-1219.

(4) Subramanian, R.; Khlystov, A. Y.; Cabada, J. C.; Robinson, A. L. Positive and Negative Artifacts in Particulate Organic Carbon Measurements with Denuded and Undenuded Sampler Configurations Special Issue of Aerosol Science and Technology on Findings from the Fine Particulate Matter Supersites Program. Aerosol Sci. Technol. 2004, 38 (sup1), 27-48.

(5) Zhang, J.; Fan, X.; Graham, L.; Chan, T. W.; Brook, J. R. Evaluation of an Annular Denuder System for Carbonaceous Aerosol Sampling of Diesel Engine Emissions. J. Air Waste Manag. Assoc. 2013, 63 (1), 87-99.

(6) May, A. A.; Presto, A. A.; Hennigan, C. J.; Nguyen, N. T.; Gordon, T. D.; Robinson, A. L. Gas-Particle Partitioning of Primary Organic Aerosol Emissions: (1) Gasoline Vehicle Exhaust. Atmos. Environ. 2013, 77, 128-139.

(7) Alexander, D. T. L.; Crozier, P. A.; Anderson, J. R. Brown Carbon Spheres in East Asian Outflow and Their Optical Properties. Science 2008, 321 (5890), 833-836.

(8) Bohren, C. F.; Huffman, D. R.; Kam, Z. Book-Review - Absorption and Scattering of Light by Small Particles. Nature 1983, 306, 625.

(9) Saleh, R. From Measurements to Models: Toward Accurate Representation of Brown Carbon in Climate Calculations. Curr. Pollut. Rep. 2020, 6 (2), 90-104.

(10) Keller-Rudek, H.; Moortgat, G. K.; Sander, R.; Sörensen, R. The MPI-Mainz UV/VIS Spectral Atlas of Gaseous Molecules of Atmospheric Interest. Earth Syst. Sci. Data 2013, 5 (2), 365-373.

(11) Davidson, J. M.; French, C. M. The Synthesis and Structure of Aromatic Boron Compounds. J. Chem. Soc. 1960, 191-195.

(12) Garratt, P. J. UV-Vis Atlas of Organic Compounds. Adv. Mater. 1993, 5 (10), 770-770.

(13) Bergmann, E. D.; Fischer, E.; Ginsburg, D.; Hirshberg, Y.; Lavie, D.; Mayot, M.; Pullman, A.; Pullman, B. Fulvenes et Ethylenes Thermochromes. $11^{\wedge}$ e Partie. Les Heptafulvenes. Bull. Soc. Chim. Fr. 1951, 18, 684-692.

(14) Friedel, A.R; Orchin, M. Ultraviolet Spectra of Aromatic Compounds.; John Wiley \& Sons: New York, 1951.

(15) Lin, P.; Fleming, L. T.; Nizkorodov, S. A.; Laskin, J.; Laskin, A. Comprehensive Molecular Characterization of Atmospheric Brown Carbon by High Resolution Mass Spectrometry with Electrospray and Atmospheric Pressure Photoionization. Anal. Chem. 2018, 90 (21), 12493-12502.

(16) Nozoe, T.; Seto, S.; Matsumura, S.; Murase, Y. The Synthesis of Azulene Derivatives from Troponoids. Bull. Chem. Soc. Jpn. 1962, 35 (7), 1179-1188.

(17) Nozoe, T.; Seto, S.; Matsumura, S. Synthesis of 2-Substituted Azulenes by Nucleophilic Substitution Reactions of 2-Haloazulene Derivatives. Bull. Chem. Soc. Jpn. 1962, 35 (12), 1990-1998.

(18) Popov, P.; Getoff, N. Radiation-Induced Degradation of Aqueous Fluoranthene. Radiat. Phys. Chem. 2005, 72 (1), 19-24.

(19) Streitwieser, A.; Suzuki, S. An HMO Treatment of the Reduction of Aromatic Hydrocarbons with Alkali Metals; Reduction of Fluoranthene. Tetrahedron 1961, 16, 153-168. 
(20) Sabbah, H.; Biennier, L.; Klippenstein, S. J.; Sims, I. R.; Rowe, B. R. Exploring the Role of PAHs in the Formation of Soot: Pyrene Dimerization. J. Phys. Chem. Lett. 2010, 1 (19), 2962-2967.

(21) Bagley, S. P.; Wornat, M. J. Identification of Five- to Seven-Ring Polycyclic Aromatic Hydrocarbons from the Supercritical Pyrolysis of $n$-Decane. Energy Fuels 2011, 25 (10), 4517-4527.

(22) Cataldo, F.; Ursini, O.; Angelini, G.; Iglesias-Groth, S. On the Way to Graphene: The Bottom-Up Approach to Very Large PAHs Using the Scholl Reaction. Fuller. Nanotub. Car. N 2011, 19 (8), 713725. 